\title{
RAD9A Gene
}

National Cancer Institute

\section{Source}

National Cancer Institute. RAD9A Gene. NCI Thesaurus. Code C106277.

This gene plays a role in both cell cycle checkpoint control and DNA repair. 